\title{
Os sentidos da revelação: Sophia e Herberto
}

\section{The meanings of revelation: Sophia and Herberto}

Paulo Ricardo Braz de Sousa

Universidade Federal Fluminense (UFF), Niterói, Rio de Janeiro / Brasil brazpr@hotmail.com

Resumo: Este ensaio busca investigar os sentidos da revelação poética nas obras de Sophia de Mello Breyner Andresen e Herberto Helder. Para tanto, é utilizado (principalmente, mas não apenas) um arcabouço teórico que atravessa as concepções filosóficas de Friedrich Nietzsche em torno da questão estética entre uma arte apolínea e outra dionisíaca, assim como suas intersecções. A partir de um exercício de leitura corpo a corpo dos poemas selecionados de ambos os autores, a ideia deste trabalho é reconhecer como estas distintas poéticas, cada qual ao seu modo, manifesta íntimas relações com a experiência do sagrado. Por fim, este ensaio projeta a possibilidade de fazer do procedimento crítico aqui desenvolvido um modo de leitura da moderna poesia portuguesa.

Palavras-chave: Sophia de Mello Breyner Andresen; Herberto Helder; revelação poética; sagrado.

Abstract: This essay tries to investigate the senses of poetic revelation in the works of Sophia de Mello Breyner Andresen and Herberto Helder. For that, a theoretical framework is used (mainly, but not only) that crosses the philosophical conceptions of Friedrich Nietzsche about the aesthetic question between an Apollonian and a Dionysian art, as well as its intersections. From an close reading exercise of the selected poems of both authors, the idea of this work is to recognize how these different poetics, each in its own way, manifests intimate relationships 
with the experience of the sacred. Finally, this article plans the possibility of making this critical procedure a way of reading modern Portuguese poetry.

Keywords: Sophia de Mello Breyner Anresen; Herberto Helder; poetic revelation; sacred.

Data de submissão: 23 de agosto de 2018

Data de aprovação: 8 de janeiro de 2019

Em poesia, é princípio estruturante a conquista de uma linguagem. Para o poeta, trata-se sempre de conquistá-la, ou por ela ser conquistado. O domínio estilístico demanda a aquisição de uma voz que, dentre todas as demais, é particularíssima em sua dicção, fenômeno que, no entanto, é concomitante a um despojamento individual que aquela mesma voz desautoriza. Neste sentido, o poema é a obra de um autossacrifício daquele que o escreve. Nele agora fala a voz de outrem: musa, texto, escritura, daemon, deus. A impessoalidade da obra é o que garante o encontro com o real, o que concede à linguagem conquistada (conquistadora) a sua autonomia. Quando dizer é ver, presentificar, então o poema se faz revelação - translado do plano profano para o sagrado.

A obra de dois poetas portugueses do século XX dão um especial tratamento a questões de ordem sagrada: Sophia de Mello Breyner Andresen e Herberto Helder, cada qual ao seu modo e ao seu tempo, laboraram a palavra poética para que nela se restituísse um vínculo primordial com as coisas. A crença nos poderes de revelação da linguagem quando em estado de poesia é uma fé na reabilitação do mundo em sua condição de reino mítico. E como todo gesto de fé (segundo humanisticamente entendo a situação de poeta), a escrita se realiza como aposta incerta. Neste sentido, a demanda poética pelo sagrado, ainda que se fundamente por um desejo de totalidade, unificação cósmica e plenitude, não exclui de seus processos a fragmentação, a descontinuidade, a falta, de maneira que a criação traça um percurso que visita territórios de terror e harmonia, angústia e equilíbrio, caos e ordem.

Regentes da (des)ordem do cosmos, os deuses personificam as nossas pulsões primitivas, anseios por um concerto universal que, por 
precariedade nossa, não alcançamos e a eles concedemos como tarefa. A cada deus cabe o seu gênio e destino, e, se me fosse incumbida a tarefa de identificar os deuses tutelares de Sophia e Herberto, designaria para eles a dualidade clássica de Apolo e Dionísio, respectivamente. Trato da questão nestes termos porque me parecem especialmente esclarecedores os sentidos da revelação na obra de ambos. Em cada caso prefigura-se uma dimensão do sagrado concernente ao poder heurístico da palavra poética, potência que, entretanto, se efetua em ambos de formas, por assim dizer, diametralmente opostas.

O desejo de uma pesquisa focada no fenômeno da revelação tem por finalidade uma investigação das faces da experiência do sagrado na poesia moderna. Os casos específicos de Sophia e Herberto, dois incontornáveis nomes da poesia portuguesa do século XX português, são acolhidos tanto (confesso) por uma aproximação afetiva minha, quanto (mais uma vez confesso) por uma intuição. Digo por uma intuição para deixar claro o caráter ainda germinal deste trabalho, no que diz respeito à dimensão estritamente acadêmica da pesquisa. Por outro lado, essa mesma intuição é resultado de um prazer de leitura das respectivas obras que não é recente. Para além desses aspectos mais pessoais, a escolha dos autores em questão obedece ao reconhecimento crítico de um aprimorado uso das imagens como chave que mobiliza as suas poéticas, e que, intuitivamente, associo a um pendor apolíneo em Sophia e dionisíaco em Herberto.

Não é o nosso intuito enclausurar os poetas nestas categorias. Se há o ensejo de construir certa polarização entre os dois nomes, tal gesto somente pode ser concebido tendo em vista a dinâmica apolíneodionisíaca em seus mais variados pontos de intersecção. Aqui, a lição passa pela filosofia de Friedrich Nietzsche e seus comentários sobre estética n'O nascimento da tragédia. A partir deles, aventaremos uma leitura das funções Apolo e Dionísio, de modo a reconhecer as suas diferenças e complementaridades no âmbito das poéticas em questão. O objetivo mais amplo é, igualmente, ordenar um quadro de referências que situe Sophia e Herberto como dois horizontes críticos a partir dos quais é possível reconhecer uma dupla vertente de leituras da moderna poesia portuguesa. 


\section{A revelação deslumbrada}

As afinidades entre os fenômenos poético e sagrado fundamentamse por um efeito de estranhamento. O êxtase testemunhado pelos místicos religiosos, como Santa Teresa D'Ávila ou São João da Cruz, manifesta-se como possessão do alheio em mim. Sob uma perspectiva mais aberta à heterodoxia da experiência sagrada, uma leitura de certos cultos pagãos ou de narrativas religiosas primitivas nos aproxima do sentido de assombro provocado pelo alheamento individual durante os ritos. Sair de si, neste âmbito, tem por finalidade a desejada confusão com o Uno - chame-o deus, natureza, cosmos. No campo da poesia, a alterização não é apenas retórica ou efeito de uma estética da objetividade (tão propalada entre os modernos), mas resultado de um verdadeiro sentimento de desapropriação consciente diante do real revelado.

Pensemos no caso de Sophia. Para a autora de Dia do mar, a poesia exige um estado de atenção ao mundo, às coisas, pois é nelas, na sua realidade mais concreta, que a poesia habita silenciosamente. O poema é um meio - o acorde que faz soar os sentidos do real em sua inteireza, para que sejam revelados em música e imagem.

É esta a hora perfeita em que se cala

O confuso murmurar das gentes

E dentro de nós finalmente fala

A voz grave dos sonhos indolentes.

É esta a hora em que as rosas são as rosas

Que floriram nos jardins persas

Onde Saadi e Hafiz as viram e as amaram.

É esta a hora das vozes misteriosas

Que os meus desejos preferiram e chamaram.

É esta a hora das longas conversas

Das folhas com as folhas unicamente.

É esta a hora em que o tempo é abolido

E nem sequer conheço a minha face.

(ANDRESEN, 2011, p. 84).

O poema, intitulado precisamente "É esta a hora...", apresenta exemplarmente alguns dos atributos que elenquei como partícipes da esfera sagrada. A começar pela explícita referência aos poetas persas 
Musharrif Od-Dîn Sa'adi e Khwāja Šamsu d-Dīn Muhammad Hāfez-e Šīrāzī (ambos notáveis figuras da cultura árabe dos séculos XII-XIII e XIV, respectivamente), cujas obras se nobilitam, entre outros aspectos, pelo forte pendor místico, Sophia parece querer se vincular a uma genealogia poética de artistas que buscam na palavra um condão de encantamento. Na leitura do referido poema, são muitos os indícios que constatam os anseios de fazer da poesia um veículo para a ação mágica: desde a construção anafórica ("Esta é a hora..."), que recupera certo tom ritualístico das invocações feiticeirais, até a imagem da possessão ("E dentro de nós finalmente fala/ A voz grave dos sonhos indolentes."), em que $\mathrm{o}$ apagamento subjetivo dá lugar ao Outro.

A alteridade experimentada neste texto coincide com um contato íntimo do sujeito lírico com a exterioridade das coisas, movimento alcançado após o silenciamento do "confuso murmurar das gentes". $\mathrm{O}$ silêncio, aqui, é o sinal mais evidente da separação do sujeito de sua integridade individual, rompimento que, por sua vez, projeta o eu para um espaço-tempo que poderíamos designar como religioso. Vale lembrar a lição de Giorgio Agamben em seu ensaio "Elogio da profanação":

Pode-se definir como religião aquilo que subtrai coisas, lugares, animais ou pessoas ao uso comum e as transfere para uma esfera separada. Não só não há religião sem separação, como toda separação contém ou conserva em si um núcleo genuinamente religioso. (AGAMBEN, 2007, p. 65)

$\mathrm{O}$ acento religioso que observamos no poema andreseniano - e que é possível considerar em toda a sua obra - está justamente posto na faculdade que as suas palavras têm de restituir as coisas nomeadas à sua essência primordial. No mundo de Sophia, as palavras buscam a justa ordem de nomeação das coisas, o que se opera como transporte destas mesmas coisas à sua realidade mítica, em que o Ser de tudo que existe se reencontra consigo mesmo e com o Todo: "Esta é a hora em que as rosas são as rosas [...]"; "Esta é a hora das longas conversas/ Das folhas com as folhas unicamente". Mas há, aqui, a possível constatação de um paradoxo: o Ser, que é a substância íntima e necessária de tudo o que é, se encontra fora de si. A alteridade do eu coordena um movimento de exteriorização que, entretanto, repõe o mundo em seus eixos.

A noção de interioridade é radicalmente questionada na poesia de Sophia, pois que o seu estatuto não se distingue de todo da ideia 
de exterioridade. É possível notar algum eco de Caeiro nesta visão de mundo - "O único sentido íntimo das cousas/ É elas não terem sentido íntimo nenhum." -, ainda que para o mestre dos heterônimos de Fernando Pessoa fique reservada uma concepção de imanência que nega todo e qualquer tipo de transcendência, o que é relativizado em Sophia. Lembro-me de uma fala de Sofia de Sousa Silva, há alguns anos, em congresso no Real Gabinete Português de Leitura, em que a ensaísta destacava a possibilidade de se reconhecer na poética andreseniana "uma transcendência na imanência". O dado transcendente na obra de Sophia é o que está à espreita do desconhecido, o espanto de haver no mundo o que chamamos de mistério: "Esta é a hora das vozes misteriosas". Mas esse mesmo mistério é, afinal, uma potente e transformadora constatação do real. Na poética andreseniana, de acordo com as palavras de Sofia de Sousa Silva, agora citada textualmente:

A ordem do mundo se revela nas coisas concretas. [...] O homem não se pode deixar perder em ilusões provocadas por espelhos deformantes ou acontecimentos contingentes. Se tiver em vista que a ordem que tudo rege o inclui - o que na linguagem do poema seria uma ligação entre a condição humana e a divina - , se não perder nunca o seu fervor mais austero e a sua exigência de si, o homem poderá entrar em consonância com os ritmos divinos. (SILVA, 2007, p. 50)

Ora, se compreendemos bem a asserção da ensaísta, na ótica de Sophia a dimensão sagrada das coisas se revela no próprio mundo dos homens, não em estado de indiferenciação com o mundo profano, mas ocupando outro registro de percepção da realidade. Em outras palavras, a poesia, como manifestação do sagrado na obra de Sophia, é um problema de ponto de vista. $\mathrm{O}$ olhar atento da poeta perscruta a superfície do mundo para, em sua dimensão concreta, adivinhar-lhe o mistério. É o que experimenta o sujeito lírico de "Esta é a hora...", cuja ânsia pela unidade primordial o leva a sair de si e, consequentemente, desconhecer-se como entidade individual: "Esta é a hora em que o tempo é abolido/ E nem sequer conheço a minha face."

A abolição do tempo de que trata o poema manifesta-se como uma supressão da ordem cronológica promovida pela "hora perfeita". Há um deslocamento temporal que consiste no translado do sujeito do mundo profano para o mundo sagrado. Nesta nova esfera, o tempo não 
obedece mais à linearidade histórica, mas à circularidade mítica. Tratase, portanto, de um tempo fora do tempo, um tempo, por assim dizer, não-histórico, mas que habita, por sobreposição e contradição, o plano da História. Segundo o pensamento de Mircea Eliade, essa dinâmica pode ser entendida sob a perspectiva dual entre tempo profano e tempo sagrado:

O tempo gastara o ser humano, a sociedade, o Cosmos, e esse tempo destruidor era o Tempo profano, a duração propriamente dita: era preciso aboli-la para restabelecer o momento mítico em que o mundo viera à existência, banhado num tempo "puro", "forte" e sagrado. A abolição do Tempo profano decorrido realizava-as por meio de rituais que significavam uma espécie de "fim do mundo". (ELIADE, 2010, p. 71).

É na situação ritualística que é o poema que o tempo se suspende e o mundo se acaba... para ser reconduzido à sua condição mítica original. A este gesto transformador damos o nome de revelação. Mircea Eliade atenta para o fato de que tal passagem, para a consciência do homem primitivo, significava "uma espécie de "fim do mundo", o que é absolutamente notável, se tivermos em conta que, na nossa cultura cristã ocidental, o livro bíblico dedicado à narração do fim dos tempos e do juízo dos eleitos é o Apocalipse. Isso porque, em grego, a expressão apokalúpsis, que originou a forma latina, designava justamente o ato de descobrir, revelar.

A poesia como um modo de ver, para Sophia, associa-se também a um modo de conhecimento da verdade. Nesse sentido, em que revelar é conhecer, a poética andreseniana estabelece laços de familiaridade com o conceito de aletheia. Segundo Marilena Chauí, "Em grego, verdade se diz aletheia, significando: não-oculto, não escondido, não-dissimulado. $\mathrm{O}$ verdadeiro é o que se manifesta aos olhos do corpo e do espírito; a verdade é a manifestação daquilo que é ou existe tal como é." (CHAUÍ, 2000, p. 123). De fato, como é sabido, revelar quer dizer justamente tirar o véu, deixar à mostra o que, antes, estava velado, abandonado ao esquecimento, de maneira que o ato da revelação, sendo um modo de conhecimento da verdade, é igualmente um gesto de afirmação da memória e preservação do passado no presente.

A realidade mítica e sagrada esconde-se sob o véu das coisas do mundo profano, faz nelas habitar o seu Ser como um mistério, e, uma vez vinda à tona, manifesta-se como verdade. E esta verdade do 
Ser, no caso de Sophia, é a sua própria condição imanente descoberta em estado de poesia: "Ali vimos a veemência do visível/ O aparecer total exposto inteiro/ E aquilo que nem sequer ousáramos sonhar/ Era o verdadeiro". (ANDRESEN, 2011, p. 675). Para além do sonho e da imaginação, assoma a verdade como deslumbramento. Não só: como revelação, aletheia e deslumbramento, que se irmanam no processo de criação poética. A "veemência do visível" de que trata o poema V da seção "As ilhas", de Navegações, diz da intensidade com que nos atinge o que é evidente. A visão é, aqui, em absoluto concreta e inteira, para além de suplantar a quimera da dimensão fantástica, e a sua particular violência advém precisamente da vertigem concernente ao "aparecer total" da realidade.

O caráter apolíneo da poesia andreseniana - como apontamos no início deste ensaio - diz respeito ao que nela é recusa do visionarismo inebriante e da voragem imagética que, em fragmentos, compõe um quadro de delírio. $\mathrm{O}$ deus Apolo rege a sua poesia como o astro lúcido que é, negando os falseamentos da verdade que se mostram sob a face da dissimulação das aparências. Um poema de Sophia é particularmente modelar no que tange a essa questão. Faço menção ao "Pescador", de Livro sexto, poema dividido em duas partes, das quais cito a segunda: "Este que está inteiro em sua vida/ Fez do mar e do céu seu ser profundo/ E manteve com serena lucidez/ Aberto seu olhar e posto sobre o mundo" (ANDRESEN, 2011, p. 385).

O olhar do sujeito lírico mantém-se "com serena lucidez/ Aberto", portanto, do lado oposto ao tumulto dos sentidos e da irracionalidade. A abertura, por outro lado, diz de uma disponibilidade ao que lhe é exterior, o que, consequentemente, supomos, é passível de alterar este mesmo olhar. Além do mais, está ele "posto sobre o mundo" - um mundo que aparece "tal como é", mas que, na inter-relação com o olho que o percebe é necessariamente um campo de sentidos em movimento. O pescador pesca, ${ }^{1}$ surpreende os sentidos do mundo, busca na água o alimento submerso e dá à luz o real em sua inteireza. $\mathrm{O}$ ato de trazer o que está dentro para fora, assim como o ato de fundir o alto e o baixo

\footnotetext{
${ }^{1}$ Lembro que a imagem do pescador possui uma clara reminiscência bíblica que remonta ao Evangelho de Lucas 5, 1-11.
} 
em seu ser ("Fez do mar e do céu seu ser profundo"), ${ }^{2}$ são propiciadores do sentimento de totalidade ("Este que está inteiro em sua vida"), índice da esfera sagrada que ronda o poema. Tal sagração se constitui como edificação da imagem - é um gesto essencialmente construtor, que busca a medida justa de todas as coisas.

Esta mesma concepção apolínea do mundo que lemos em Sophia, em que o sujeito se mantém em sua hybris, respeitando os limites da sua individualidade, também pode ser singularmente deslocada - e a revelação do Ser a partir de uma "serena lucidez" agora apresenta a sua face de espanto sob a égide do deslumbramento. Não se trata de uma desmedida, mas de uma vertigem das formas provocada pelo excesso de medida. Não há propriamente ruptura ou transgressão, mas uma espécie de simultânea sensação de paralisia e movimento em que se dá a ver o real em um sobressalto: "Reino de medusas e água lisa/ Reino de silêncio luz e pedra/ Habitação das formas espantosas/ Coluna de sal e círculo de luz/ Medida da Balança misteriosa” (ANDRESEN, 2011, p. 387).

O poema "Reino", que acabo de citar, compreende as premissas do que poderíamos associar aos fundamentos de uma estética apolínea: senso de equilíbrio na distribuição dos versos, correspondência sintática na organização dos sintagmas nominais, escolha vocabular que valoriza um léxico luminoso. Entretanto, é esta mesma disposição dos termos poéticos que faz emergir o mistério. Ora, o mistério é justamente a zona encoberta, interdita, a qual não se acessa menos por obscuridade do que pela excessiva luz. No poema se busca a justa medida (lá encontramos a Balança, inscrita assim em maiúscula), mas o conhecimento dessa medida, diferentemente da esterilidade do saber técnico, é uma ciência espantosa.

É preciso destacar que a ideia de reino para a poética andreseniana é particularmente importante. Na sua "Arte poética I", um narrador descreve uma sua visita à loja de barros em Lagos, o que desencadeia uma série de reflexões acerca da criação. Nesse caso, reino é o espaço em que cada coisa no mundo restitui as ligações entre si, espaço portanto de comunhão, sagrado. O mundo profano é um mundo dividido, "Mundo

\footnotetext{
${ }^{2}$ Há também aqui ecos da doutrina hermética atribuída ao legislador e filósofo egípcio Hermes Trismegisto. Uma das mais referenciadas reflexões deste pensador está sintetizada na Lei da Correspondência, segundo a qual "o que está em cima é como o que está em baixo" - fórmula que está nas bases do conhecimento da alquimia.
} 
que pode ser um habitat mas não é um reino." (ANDRESEN, 2011, p. 838). A tarefa da poeta é redescobrir a aliança oculta entre as coisas, fazer nelas brilhar o seu Ser por meio de uma específica maneira de olhar, limpidamente: "Talvez a arte deste tempo tenha sido uma arte de ascese que serviu para limpar o olhar." (ANDRESEN, 2011, p. 837).

Como viemos desenvolvendo, embora uma tradicional concepção estética apolínea se circunscreva à medida e ao seu caráter exclusivamente organizador, a poesia de Sophia - sem perder esses atributos - aciona a escrita como veículo de passagem para uma esfera sagrada, em que a claridade de tudo cega, e o que temos é uma (não) visão do espanto: "Olho para a ânfora: quando a encher de água ela me dará de beber. Mas já agora ela me dá de beber. Paz e alegria, deslumbramento de estar no mundo, religação." (ANDRESEN, 2011, p. 837). Pedro Eiras, em um importante ensaio sobre Sophia, descreve certa imagem do terror em sua poesia a partir de uma investigação em torno da "face nocturna" dos deuses. Desde as investigações de Nietzsche sobre $O$ nascimento da tragédia, a observação da dinâmica entre as pulsões apolínea e dionisíaca nas artes apresenta-se como um interessante modo de leitura que associa estética e vida ${ }^{3}$. De fato, para o filósofo alemão, a vida apenas se reconcilia com a tragédia que é a consciência da própria morte na expressão artística - "pois só como fenômeno estético podem a existência e o mundo justificar-se eternamente" (NIETZSCHE, 2007, p. 44) -, dado que nos torna evidente a íntima relação entre a arte e o duplo movimento de criação e destruição. Em Sophia não é diferente e Pedro Eiras chama atenção a essa dualidade:

Não ignoro que há em Sophia a mais depurada serenidade, simetria, equilíbrio; mas há também o terror. E não apenas terror do homem perante o homem, com a salvaguarda possível de uma serenidade olímpica, imutável; os próprios deuses, direi agora, podem ser terríveis [...]. (EIRAS, 2011, p. 29)

\footnotetext{
${ }^{3} \mathrm{O}$ famoso ensaio começa justamente com a seguinte asserção: "Teremos ganho muito a favor da ciência estética se chegarmos não apenas à intelecção lógica mas à certeza imediata da introvisão de que o contínuo desenvolvimento da arte está ligado à duplicidade do apolíneo e do dionisíaco, da mesma maneira como a procriação depende da dualidade dos sexos, em que a luta é incessante e onde intervêm periódicas reconciliações." (NIETZSCHE, 2007, p. 24).
} 
$\mathrm{O}$ terror de que fala Eiras decerto habita a poesia andreseniana como um índice de morte e negatividade. O ensaísta começa por desenvolver a sua leitura a partir dos versos de "Musa", poema de Livro sexto: "Musa ensina-me o canto/ Que me corta a garganta" (ANDRESEN, 2011, p. 391). Não iremos aqui retomar o estudo já realizado por Eiras (remeto o leitor interessado ao seu trabalho); o nosso intuito é perseguir a feição igualmente terrível da experiência apolínea - quando a claridade e o silêncio se fazem índices de uma espantosa expressão do sublime.

Talvez a forma mais surpreendente disso que procuro dizer se encontre no informe soneto de Navegações que agora cito:

Navegavam sem o mapa que faziam

(Atrás deixando conluios e conversas

Intrigas surdas de bordéis e paços)

Os homens sábios tinham concluído

Que só podia haver o já sabido:

Para a frente era só o inavegável

Sob o clamor de um sol inabitável

Indecifrada escrita de outros astros

No silêncio das zonas nebulosas

Trémula a bússola tacteava espaços

Depois surgiram as costas luminosas

Silêncios e palmares frescor ardente

E o brilho do visível frente a frente

(ANDRESEN, 2011, p. 676)

Para um leitor-marinheiro de primeira viagem, o texto recémcitado é um poema de treze versos distribuído em cinco estrofes. $O$ engano consistiria na não-leitura do segundo verso do soneto que, afinal, é um não-verso: "Navegavam sem o mapa que faziam/ Em tensa relação dialógica com a forma fixa clássica, esta obraprima de Sophia faz do espaço branco da folha a própria expressão do desconhecido, aquilo que depois o eu lírico denominará como o "inavegável" ou o "inabitável". A privação do mapa, este agudo ponto de negatividade, não impede aqueles que navegam - no mar, no texto, na leitura -; pelo contrário, os força a enfrentarem o desconhecido, o 
que fatalmente os leva a descobrir o novo, aquilo para que não há ainda linguagem e é puro silêncio (palavra que aparece duas vezes no soneto de Sophia).

\section{A revelação extática}

O silêncio de Sophia, luminoso, ardente, manifesta-se como "o brilho do visível frente a frente". É, portanto, uma evidência, antes de tudo - um sinal de franca visibilidade na lucidez do eu lírico, que, afinal, prescinde de palavras (ou quase isso, pois o silêncio ainda é algo dito, se faz no poema como uma maneira de dizer). Parto do silêncio andreseniano para encontrá-lo na voz de outra das mais potentes vozes líricas do século XX português: Herberto Helder.

$\mathrm{O}$ contraponto almejado por este ensaio, à primeira vista, é bastante simples: diante da claridade clássica da poesia de Sophia, Herberto representaria uma força obscura, ao mesmo tempo contrária e complementar. Também em termos clássicos, perante a regência apolínea daquela, poderíamos dizer que a poesia deste é um exemplar de potência dionisíaca. É possível traçar, de fato, um quadro comparativo pautado nesta dinâmica: o núcleo da poética andreseniana se faz de justa medida, equilíbrio e claridade, enquanto a poética herbertiana é movida de transgressão, ébrio desequilíbrio e trevas. No entanto, em ambos os casos notamos certo anseio de fazer com que a palavra restitua o mundo à sua dimensão mítica. Como que por caminhos opostos, os dois poetas se encontram no mesmo ponto, em que a poesia faz revelar a experiência do sagrado.

Pode ser curioso pensar esse movimento de restituição do mundo à sua situação sagrada que a poesia proporciona, e que, afinal de contas, também não deixa de ser um modo de se encontrar com a verdade. Esse sentido da revelação como aletheia, o próprio Herberto adivinha na poesia andreseniana, como atesta um seu comentário sobre a poesia da autora de Livro sexto, em uma correspondência a ela enviada, e datada de 5 de junho de 1962. Nessa altura, o poeta faz lembrar um jovem Herberto, partilhando do espanto que a experiência de leitura da obra de Sophia proporciona: 
A cada livro novo seu que leio, sente-se o antigo encantamento da minha primeira juventude, quando descobri a sua poesia. Nunca lhe contei? Numa tarde, na Ilha da Madeira, tinha eu a idade maravilhosa que já não sei, descobri numa livraria o seu «Poesia». $\mathrm{E}$ foi um dos mais belos encontros da minha vida. Não há aqui literatura: tudo isto é verdadeiro. (HELDER, 2011).

$\mathrm{O}$ excerto que colho da missiva de Herberto não me interessa em nada enquanto documento da intimidade da pessoa que ali conta as suas memórias. $\mathrm{O}$ que, de fato, me instiga é a observação de como o texto de Herberto é certeiro no apontamento do que viemos tratando neste ensaio. A descoberta, o encantamento, a verdade. Vale notar que só o verbo descobrir surge por duas vezes nesse curto fragmento. Afora a expressão "idade maravilhosa que já não sei", sintomática de uma associação da infância com o período mítico e sagrado, portanto, de um tempo fora do tempo. Aqui, onde o "antigo" e a "primeira juventude" se fundem - sem contradição alguma -, aqui é o espaço em que a linguagem se faz experiência, em que a linguagem é a experiência. Por isso, "Não há aqui literatura: tudo isto é verdadeiro." (grifo nosso).

Herberto, ao pensar a poesia andreseniana, talvez nos ensine alguma coisa sobre o seu próprio fazer poético, justamente no que ele também apresenta de efeito revelador. Mas se há uma clara tangência no que diz respeito à crença no poder heurístico da palavra (particularidade tão moderna e partilhada por Herberto e Sophia), há também obscuridades que distanciam e distinguem a poesia de ambos. As imagens e a sintaxe herbertianas são flagrantemente mais tortuosas, em certo sentido, quase barrocas, no que insinua com o seu hermetismo. Se por um lado, Sophia prima por uma claridade clássica que se dá a ver tanto na forma quanto no conteúdo, Herberto busca as zonas de trevas para nelas tentar dar a luz a outro tipo de visibilidade: uma visibilidade turvada, impactada pelo choque das imagens. Nesse sentido, o visionarismo da poesia herbertiana, se porventura evoca alguma memória de Sophia, a realiza - suponho em sentido diametralmente oposto. O que em uma é deslumbramento (por excesso de medida), no outro é êxtase (por transgressão da medida).

Um poema em particular me remete a esse possível diálogo poético que viemos construindo entre os dois amigos. Do livro Lugar, destaco o poema-dedicatória "Aos amigos" que serve de pórtico de abertura à obra: 
Amo devagar os amigos que são tristes com cinco dedos de cada lado.

Os amigos que enlouquecem e estão sentados, fechando os olhos, com os livros a arder para toda a eternidade.

Não os chamo, e eles voltam-se profundamente dentro do fogo.

- Temos um talento doloroso e obscuro.

Construímos um lugar de silêncio.

De paixão.

(HELDER, 2014, p. 127)

O poema em questão, texto que parece reivindicar uma aliança entre não só amigos, mas amigos poetas, indica, por meio de uma série de imagens que nos remete ao universo do ofício da escrita (os dedos, os livros, o talento), alguns dos topoi da poética herbertiana que mais de perto aqui nos interessa. A loucura ("Os amigos que enlouquecem e estão sentados [...]"), primeiro desses topoi que gostaria de assinalar, marca da desrazão dionisíaca que rege esta poesia, surge em simultâneo com a condição sentada dos amigos, condição que simbolicamente aponta para a situação criativa, como é possível notar em outros passos da obra de Herberto. Sendo assim, loucura e criação são tópicos correlativos, de modo que podemos inferir ser a criação uma espécie de loucura, ou um gesto por ela movido, o que faz do poema (o objeto criado) uma obra que resguarda sentidos à margem da lógica racional - organizadora do mundo profano do trabalho e da produtividade. A obra poética é, por assim dizer, em termos herbertianos, um anti-trabalho, uma ação geradora de improdutividade. Em Herberto, a criação é consumo excessivo, dispêndio. Talvez por esse motivo os amigos evocados tragam "os livros a arder para toda a eternidade": imagem de ecos infernais que, por analogia, pode nos remeter a Lúcifer, o Príncipe das Trevas.

O segundo desses topoi é precisamente a obscuridade: “- Temos um talento doloroso e obscuro". A associação entre o deus pagão Dionísio e a representação cristã do Mal e da insubordinação em Lúcifer, muito tem que ver com certa obscuridade inerente ao culto dionisíaco, em que o torpor do vinho restitui o homem a uma violência primordial por meio do sacrifício sangrento, mais próxima da bestialidade, e tão refutada pelo cristianismo. Mas se, por um lado, Dionísio e Lúcifer se identificam por seu caráter destrutivo, igualmente se aproximam por 
serem reveladores de um saber - não aquele promovido pela razão lógica, mas pela transgressão. Dionísio é o deus da tragédia: aquele que insufla nos corações humanos o desejo de busca por um conhecimento para além dos limites já conhecidos. Lúcifer é o portador do archote, aquele que traz a luz do saber e que tentou o homem a provar o fruto da Árvore do Bem e do Mal. Ambos promovem, por ação do desejo (da paixão), a busca por este conhecimento indizível, por isto - pelo silêncio ("Construímos um lugar de silêncio").

Trato da questão do silêncio, pois creio que esse tópico (o terceiro, ao qual já havia aludido) seja particularmente forte para o desenvolvimento de um estudo comparativo entre os dois poetas analisados. É porventura no silêncio que ambos encontram a expressão mais candente de suas artes poéticas. Há, todavia, singularidades que tornam essas poéticas radicalmente diferentes. Enfrentemos, sem mais tardar, outro poema de Herberto, para observar tais dessemelhanças:

nada pode ser mais complexo que um poema,

organismo superlativo absoluto vivo,

apenas com palavras,

apenas com palavras despropositadas,

movimentos milagrosos de míseras vogais e consoantes,

nada mais que isso,

música,

e o silêncio por ela fora

(HELDER, 2014, p. 663)

Em um primeiro momento, o referido poema de Herberto descreve um movimento, constante em sua obra, caracterizado pela homologação entre texto e corpo. Aqui, as palavras tomam para si funções corporais, enquanto o corpo do poeta assume particularidades gramaticais. Tratase de verdadeira fusão alquímica entre elementos díspares, que, no mundo poético herbertiano, se dá por força de ação mágica. O condão de encantamento da palavra, que todo o mundo reúne em si, se efetua por meio de determinada disposição do texto/corpo capaz de restituir as coisas à sua unidade: algo como aqueles "movimentos milagrosos de míseras vogais e consoantes".

Há miséria no poema, pois são parcas as palavras que o constituem, mas, ainda assim, nada mais que vogais e consoantes, fazse o milagre. Talvez por ser também puro movimento vital, "organismo 
superlativo absoluto vivo" (curiosa intersecção de corpo e texto, segundo a análise morfológica de grau deste adjetivado tecido corporal), o poema participa, com toda a sua crueza, da esfera sagrada, pois é neste encontro fundamental com a realidade da vida que nos religamos à nossa condição primordial.

As ideias de pureza e primordialidade são controversas, sobretudo se tratadas em termos de busca por uma virginal originalidade no dizer poético. Ora, nesse caso, não se trata de um uso da linguagem anterior ao que quer que seja, fruto de uma consciência genial, salve todo o romantismo herbertiano, mas de um notável exemplo de trabalho poético que, por meio de uma especial organização de palavras tantas vezes já ditas, busca dizer o espanto do mundo, como se visto pela primeira vez. É por meio deste exercício que concebemos a ideia herbertiana de revelação. O canto e a música são o sinal de um almejado concerto entre as coisas, justamente animadas por força de encantamento (basta retomar o citado verso "movimentos milagrosos de míseras..." para notar a musicalidade promovida pela aliteração das bilabiais). Mas há também silêncio, pela música fora, porque este ato de encantar restitui cada corpo ao seu estado primordial, e já aqui nada precisa ser dito ou nomeado.

O silêncio, como veremos, é igualmente a marca do mistério, que, em Herberto, encontra na experiência erótica um meio privilegiado para lhe sondar a face. Face que há de ser perpetuamente misteriosa: "A escrita é a aventura de conduzir a realidade até ao enigma, e propor-lhe decifrações problemáticas (enigmáticas)." (HELDER, 2013, p. 138). Como é sabido, mas vale a pena recordar, o sentido do erotismo herbertiano, ainda que perpasse a vivência da sexualidade - "Em cada mulher existe uma morte silenciosa." (HELDER, 2014, p. 19) -, se realiza principalmente como experiência cósmica, o que, em termos andresenianos, poderíamos chamar a sua "explicação com o universo" (ANDRESEN, 2011, p. 839). Por meio do amor (experiência profundamente estética), Herberto tenta justificar a sua existência no mundo, reconciliando-se tragicamente com ele.

O tom trágico, aqui, é a sua feição dionisíaca por excelência. Apolo é o deus que rege aquilo que Nietzsche designa de "principium individuationis [princípio de individuação]" da subjetividade, enquanto que Dionísio é o deus do excesso, da transgressão e do transbordamento. O deus trágico não reconhece limites, logo, a forma estética que melhor o caracteriza é, paradoxalmente, o informe, o inacabado. Não é à toa 
que uma das concepções críticas mais pertinentes para pensar a poesia herbertiana seja a de metamorfose, pois que, para o autor de $A$ colher na boca, a atividade criativa é entendida sempre como processo. Quando abordamos a confusão entre corpo e texto em sua poesia, não mais desejamos apontar do que este anseio por aproximar a arte dos movimentos vitais, que, por sua vez, são um perpétuo fazer e desfazer, aliança trágica entre vida e morte. Por isso mesmo a expressão de Eros (com toda a sua afinidade ao culto dionisíaco ${ }^{4}$ ) ganha tanta força na sua obra.

O erotismo, assim como o culto dionisíaco, se caracteriza por um gesto de dispêndio (as "palavras despropositadas" do poeta). O gasto imponderável é observado tanto nos rituais de sacrifício pelo derramamento de sangue, como nas festas orgiásticas pelo derramamento do sêmen, ambos atos dispendiosos que impulsionam o sujeito que deles participa a vivenciar o colapso da própria individualidade diante do terror provocado por todo aquele excesso. Nessas práticas, o que notamos é uma exuberância da vida que, em seus limites, se encontra com a morte. O gemido do homem quando alcança o orgasmo assemelha-se ao grunhido do animal na cerimônia expiatória: nas duas circunstâncias, o que é posto em cena é um transbordamento, o exercício de uma atividade absolutamente improdutiva (portanto alheia ao mundo profano do trabalho). A ocorrência de tais práticas se fundamenta em um princípio contrário ao da individuação, e o terror provocado pelo gasto desmedido revela ao homem o mundo sagrado como abertura à alteridade. Como nos lembra Nietzsche:

Se a esse terror acrescentarmos o delicioso êxtase que, à ruptura do principium individuationis, ascende do fundo mais íntimo do homem, sim, da natureza, ser-nos-á dado lançar um olhar à essência do dionisíaco, que é trazido a nós, o mais de perto possível, pela analogia da embriaguez. (NIETZSCHE, 2007, p. 27)

\footnotetext{
${ }^{4}$ George Bataille, em As lágrimas de Eros, afirma que "O culto de Dionisos foi essencialmente trágico. E foi ao mesmo tempo erótico, foi-o numa desordem delirante; e, como sabemos, por ter sido erótico, o culto de Dionisos foi trágico... Era sobretudo trágico, aliás, e num horror trágico é que o erotismo acabou por fazê-lo entrar." (BATAILLE, 2012, p. 67). Ficam evidentes, a partir desta reflexão, as ligações entre Eros, Dionísio e o espírito trágico.
} 
Ora, o estado de embriaguez é que permite ao sujeito a vivência extática. E a revelação herbertiana, como viemos tratando, se dá como êxtase corporal advindo da experiência erótica: "Por isso é que estamos morrendo na boca/ um do outro. Por isso é que/ nos desfazemos no arco do verão [...]”' (HELDER, 2014, p. 25-26). É possível notar esta confluência entre delírio erótico e embriaguez dionisíaca na poesia de Herberto, ambos atuando no sentido de fazer com que o sujeito experimente o que seja sair de si (o que etimologicamente significa o ekstasis), para ser habitado pela própria morte.

Com uma flecha em meu flanco, cantarei.

E enquanto manar de minha carne uma videira de sangue, cantarei seu sorriso ardendo, suas mamas de pura substância, a curva quente dos cabelos.

Beberei sua boca, para depois cantar a morte e a alegria da morte.

(HELDER, 2014, p. 20)

Nesses versos de "O amor em visita", reconhecemos a manifesta confluência entre Eros e Dionísio, este pela imagem da videira e da ébria alegria, aquele pela flecha e pelo corpo amado e transubstanciado no corpo amante. No poema com que Herberto se estreia em poesia, sobressai essa marca dionisíaca (para não dizer nietzschiana), que é o móvel de sua poética, notável em vários passos da sua produção. As referências míticas e herméticas ("nada pode ser mais complexo que um poema") da sua poesia fazem-na situar-se em um território de certa obscuridade. Sobretudo em consonância com a dimensão alquímica da obra herbertiana (e naturalmente nos remetendo ao conto d'Os passos em volta), Maria Estela Guedes batiza o seu pioneiro estudo de Herberto Helder: poeta obscuro, que, apesar de algumas interpretações controversas, abre importantes portas de leitura.

Segundo a ensaísta, "Toda a obra de $\mathrm{HH}$ reata e estreita laços com a secreta verdade dos seres, numa linguagem obscura à força de exprimir o que há de mais simples na existência [...]" (GUEDES, 1979, p. 21, grifos nossos). De acordo com esta afirmação, poderíamos depreender que a equivalência entre a linguagem obscura do poeta e a simplicidade da existência consiste no fato de que a obscuridade, em Herberto, é sempre resultante de um ato de revelação. O desnudamento do real por 
ação dionisíaca apenas gera novas zonas de obscuridade, ou seja, regiões de perpétuo mistério por se revelar. Não seria demais afirmar que, nessa poesia, a revelação é uma tarefa infernal.

De fato, a poesia herbertiana é uma arte obscura. Mas é também uma arte pirotécnica - "Quero na escuridão revolvida pelas luzes/ ganhar baptismo, ofício." (HELDER, 2014, p. 494) -, o que, em certo sentido, para além de algum barroquismo, reforça o seu caráter noturno. As luzes herbertianas são os fenômenos incandescentes, a centelha da nenhuma esperança (?) de sabermo-nos seres para a morte, mas não deixam de ser luzes e, por conseguinte, nos iluminar.

\section{Conclusão}

Este trabalho poderia se estender indefinidamente, a partir da discussão de momentos da obra de Sophia e Herberto. Os limites deste ensaio impedem esta tarefa por agora. Supomos, entretanto, que a dinâmica de estudo aqui proposta possa proporcionar a abordagem crítica de outros autores, de maneira que a dualidade entre Apolo e Dionísio (como elementos estruturantes de uma estética da medida e outra da desmedida, respectivamente) possa ser compreendida como um modo de leitura das tensões existentes entre as diferentes poéticas no contexto português.

\section{Referências}

AGAMBEN, Giorgio. Profanações. Tradução de Selvino J. Assmann. São Paulo: Boitempo, 2007.

ANDRESEN, Sophia de Mello Breyner. Obra poética. Lisboa: Caminho, 2011.

BATAILLE, Georges. As lágrimas de Eros. Tradução e apresentação de Aníbal Fernandes. Lisboa: Sistema Solar, 2012.

BÍBLIA de Jerusalém. Tradução de Euclides Martins Balancin et al. São Paulo: Paulus, 2002.

CHAUÍ, Marilena. Convite à filosofia. São Paulo: Ática, 2000.

EIRAS, Pedro. A face nocturna: dos deuses em Sophia de Mello Breyner Andresen. Colóquio/Letras, Lisboa, n. 176, p. 28-37, 2011. 
ELIADE, Mircea. O sagrado e o profano. Tradução de Rogério Fernandes. São Paulo: Martins Fontes, 2010.

GUEDES, Maria Estela. Herberto Helder: poeta obscuro. Lisboa: Moraes, 1979.

HELDER, Herberto. Carta de Herberto Helder para Sophia. Santarém, 5 de junho de 1962. In: Sophia de Mello Breyner Andresen no seu tempo: momentos e documentos. 2011. Disponível em: $<$ http://purl. pt/19841/1/1950/galeria/f31/foto1.html>. Acesso em: 3 ago. 2018.

HELDER, Herberto. Photomaton \& vox. Porto: Assírio \& Alvim, 2013.

HELDER, Herberto. Poemas completos. Porto: Porto Editora, 2014.

NIETZSCHE, Friedrich. O nascimento da tragédia. Tradução, notas e posfácio de J. Guinsburg. São Paulo: Companhia das Letras, 2007.

SILVA, Sofia Maria de Sousa. Reparar brechas: a relação entre as artes poéticas de Sophia de Mello Breyner Andresen e Adília Lopes e a tradição moderna. 2007. Tese (Doutorado) - Pontifícia Universidade Católica do Rio de Janeiro, Rio de Janeiro, 2007. 